Saudi Journal of Business and Management Studies Abbreviated Key Title: Saudi J Bus Manag Stud ISSN 2415-6663 (Print) |ISSN 2415-6671 (Online) Scholars Middle East Publishers, Dubai, United Arab Emirates Journal homepage: https://saudijournals.com/sjbms

Original Research Article

\title{
The Effect of Economic Value Added and Financial Performance on Stock Return
}

\author{
Nopi Tikasari ${ }^{1}$, Dwi Asih Surjandari ${ }^{2 *}$ \\ ${ }^{1}$ Student of Master Program in Accounting, Universitas Mercu Buana, Jakarta, Indonesia \\ ${ }^{2}$ Assistant Professor, Department of Accounting, Universitas Mercu Buana, Jakarta, Indonesia
}

DOI: $10.36348 /$ sjbms.2020.v05i06.005

| Received: 25.05.2020 | Accepted: 07.06.2020 | Published: 21.06.2020

*Corresponding author: Dwi Asih Surjandari

\section{Abstract}

The aim of this study is to examine the effect of economic value added (EVA) and financial performance on stock returns of mining companies listed on the Indonesian stock exchange from 2012-2018. The samples used is purposive sampling techniques based on determined criterias, the sample is 12 of 84 (population) companies. While the data analysis method used is the panel regression analysis using Microsoft Excel software and eviews 10. The independent variables used is EVA and Financial Performance which proxied by Current Ratio, Debt to Equity Ratio, Net Profit Margin, and Earning Per Share, meanwhile the dependent variable is Stock Returns. The results found that partially EVA and Net Profit Margin has a positive and significant effect on stock returns meanwhile (2) the current ratio, debt-to equity ratio and) earnings per share does not have and simultaneously all variables affects Stock Return.

Keywords: Economic Value Added, Current Ratio, Debt to Equity Ratio, Net Profit Margin, and Earning Per Share, and stock returns.

Copyright @ 2020: This is an open-access article distributed under the terms of the Creative Commons Attribution license which permits unrestricted use, distribution, and reproduction in any medium for non-commercial use (NonCommercial, or CC-BY-NC) provided the original author and source are credited.

\section{INTRODUCTION}

One of the capital market instruments most widely known to the public is stocks. Stocks are one of the capital market instruments that investors are most interested in because they provide attractive returns. Irham [1] states that Shares are proof of ownership of capital / funds in a company. The Shares are in the form of a sheet of paper that is clearly listed in nominal value, the name of the company and is followed by rights and obligations that are explained to each holder. And a share that is ready for sale.

The Indonesia Stock Exchange as a capital market that can be used as an alternative funding for all sectors of the company in Indonesia. One alternative funding is through the issuance and sale of shares on the Stock Exchange. Seeing this open opportunity, companies are competing to trade their shares in the capital market.
For capital market investors is an effective means of investing their capital in order to obtain profits (Return). For investors, the higher the company's return, the more interested investors will invest their capital because the greater the profits they get. As for management, the higher the company's return, the better the company's performance and management in generating profits.

In analyzing the company's financial performance as measured by financial ratios to find out and evaluate the level of success of the company based on financial activities that have been carried out to make it easier to make investment choices on a company's shares. EVA is an indicator of company performance that has a correlation with stock returns and Eva is an addition to the value of an investment.

In this study, the mining sector was chosen as the object of research because it is seen from the geographical side of Indonesia which is a country with an island structure that contains a lot of natural 
resources in the form of mining products. In addition, the mining sector also provides profitable profits in investing. After experiencing a slowdown last year, mining-based shares again attracted the attention of capital market investors and mining shares this time could be a pillar of the strengthening of the Indonesian stock index. Since the beginning of the year until October 14, 2016, the mining sector stock index has risen 53.35 percent, beating the Composite Stock Price Index (CSPI) which only rose 17.37 percent in the same period.

As seen on Graph 1 as of 15:30 WIB today, October 17, 2016, the Jakarta Composite Index (JCI) has risen 0.31 percent driven by the mining index increase of 1.66 percent. The shares of listed coalrelated companies that rose the most in today's trading were PT Delta Dunia Makmur Tbk (DOID) with an increase of 10.4 percent to Rp530 from the previous closing of Rp480. Then, in second place was PT Bumi Resources Tbk (BUMI), which rose 8 percent to Rp82. Shares of coal producer PT Harum Energy Tbk (HRUM) also rose by 6.7 percent to Rp1,590 and PT Tambang Batubara Bukit Asam Tbk (PTBA) rose 5 percent to Rp12,300. PT Indo Tambang Raya Megah Tbk (ITMG) and PT Adaro Energy Tbk (ADRO) also rose respectively by 3.7 percent and 2.5 percent. With the increase in stock returns in mining in 2016 which affected the increase in the Composite Stock Price Index (CSPI) will had positive effect on economy.

The factors that affected stock return is so many, but these two variables EVA and Financial Performance which proxied by using CR (Current Ratio), DER (Debt to Equity Ratio), NPM (Net Profit Margin), and EPS (Earning Per Share) still found inconsistency in the results, that is why based on these matters and the importance of Stock Return in economy this study is intended.

\section{LITERATURE REVIEW \\ Agency Theory}

Purposed by Jensen and Meckling [2], the agency theory appears in the background condition where the owner of the company (principal) pointed the others (agent), usually by a contract [3] to run their business with the mission to make the principal to be more and more prosperous by time to time. For that mission the agent, the management make all business action with empowered all the economic source to attain that mission. Periodically, management is valued their performance by the principal to make sure that the goals is on the track and one of performance measurement is the level Stock Return.

\section{Signaling Theory}

The separation between shareholder and management has driven the asymmetry information about the company where management knows everything about firm operation while share holder know only if they informed by management. The nature of management task to make shareholder wealthier push management to send signals through all information they deliver which categorized as good or bad news [4]. The stock return information could be good or bad news for the shareholder.

\section{Stock Return}

Stock return is one of important reason for investor to make investment decision [5] usually come from 2 sources which is: a) yield that counted as cash flow percentage related stock price and b) capital gain which refers stock price changing during transaction. With assumption 0 dividend, SR could be counted as the percentage of stock price changing year now and last year with formula: $\mathrm{SR}=(\mathrm{P} 1-\mathrm{P} 0) / \mathrm{P} 0$, where $\mathrm{SR}=$ Stock Return, $\mathrm{P} 1=$ Stock Price year now, $\mathrm{P} 0=$ last year stock price.

\section{Economic Value Added (EVA)}

Amin [6] describes that EVA is a measure of performance based on the value for shareholder, meanwhile Suad \& Enny [7] explains that EVA is a good measurement throughout could add value for the shareholder. Further Brigham \& Houston [8] states that Economic Value Added (EVA) is the economic profit which calculated as EVA $=$ NOPAT - $($ Cost Of Capital $\mathrm{x}$ Capital Employed), where NOPAT = Net operating Profit After Tax, WACC $=$ Weighted Average Cost of Capital and Capital Employed is capital used during certain period, based on this formula concluded that EVA has positive effect on Stock Return. The studies of Babatunde and Evuebie [9], Dedi et al., [10], Adil and Muhammad [11] and Banerjee [12], supports this theory. Based on the description, it can be concluded that there is a positive influence of EVA value on stock returns, that is a positive EVA reflects a good performance. Based on this, EVA value will move in the same direction with the Stock Return. The EVA formulated as EVA = NOPAT - Capital Charge, where NOPAT is Net Operating Profit after Tax and Capital Charge is Weighted Average Cost of Capital.

\section{Current Ratio (CR)}

The current ratio measures the ability of current asset to cover its current liability, the ability of current asset in funding its short term debt Mulyawan [13], Kasmir [14] and Irham [1], the greater the current ratio indicates that the profits owned by the company are also large because the company has utilized its assets in generating profits, so that if the company's profits are large, the rate of return received by investors will be large. The Current Ration has positive effect on Stock Return which was supported by study of Obala and Olweny [15]. The Current Ratio is measured as Current Asset divided by Current Liabilities.

\section{Debt Equity Ratio (DER)}

Siege and Shim in Irham [1] states that DER is: "The measure used in analyzing financial statements 
to show the amount of collateral available to creditors.", While Halim and Sarwoko [16] explains that DER is the relation between long term liability issued by creditor and the equity granted by shareholder, and about DER calculation, Kasmir [14] pointed that DER is the ratio of long term liability to equity. The correlation between DER and Stock Return could be explained that a high DER indicates a higher risk of the company in paying term liabilities long. This adversely affects the value of the company so that this will reduce stock returns. And conversely the lower the risk of the company in paying long-term obligations will have a good effect on the value of the company so that this will increase stock returns. This premise supported by study of Dedi et al., [10] showed that the DER had a significant negative effect on stock returns. The DER is formulated as the ratio of the long term liability to equity.

\section{Net Profit Margin (NPM)}

Mulyawan [13] declares that net profit margin (NPM) shows firm's ability in generating net profit after tax, while Brigham and Houston [17] explain that NPM measures firm net profit compare to its sales. The higher the NPM indicates that the increasing net profit achieved by the company. With the increase in the NPM, there will be an increase in attractiveness of investors to invest the company's shares also tends to increase. The higher investors invest their shares, then stock returns will increase. A high NPM reflects the high firm could earn net profit, the high NPM will attract investor and it will drive the stock price to rise, NPM has a positive correlation with the Stock Return. This theory supported by studies of Maryyam [18]. The NPM is measured as the proportion of Earning after Tax to Sales.

\section{The Earning Per Share (EPS)}

The Earning Per Share (EPS) shows firm ability to generate profit for every outstanding share [19] calculated as the book ratio profit per share as an indicator of the management performance in having profit for the shareholder [14]. The higher the EPS, the more success the management in attaining profit, the more attracted investor to make financial decision an at the end will drive the Stock Return. The EPS has positive relation with Stock Return. The amount of EPS is counted as earnings after taxes (EAT) divided the number of common shares outstanding [1]. The EPS calculated as Earning after Tax divided by outstanding stocks.

\section{Previous Researches}

Babatunda et al., [9] reported that EVA has a positive relationship to stock returns in Nigeria, but opposite result recorded by Adil and Muhammad [11] showed that EVA has a weak but significant negative relationship on stock returns in the long run.

Study about the effect of Current Ration (CR) on Stock Return (SR) done by Obala and Olweny [15] with the results that $\mathrm{CR}$ has a moderate but positive effect, opposite result filed by Allozi et al., [20] announced that $\mathrm{CR}$ do not have a significant relationship with stock returns.

The research about the impact of Debt to Equity Ratio (DER) on SR appears on works by Dedi et al., [10] found that DER had a significant negative effect on SR, while Allozi et al., [20] showed that DER did not have a significant effect on SR and Banerjee [12] showed that DER cannot predict stock returns and therefore can safely be considered statistically insignificant.

The study about impact of Net Profit Margin (NPM) on SR found on Maryyam [18] stated that NPM had a significant positive impact on SR, while Allozi et $a l .$, [20] mentioned that NPM did not have a significant effect on SR and Dedi et al., [10] wrote that NPM (Net Profit Margin) had a significant negative effect on SR.

The work concerning the effect of Earning Per Share (EPS) on Stock Return (SR) found Allozi, et al., [20] stated that EPS had a significant effect on SR, while Anwaar [18] showed that EPS had a significant negative impact and Banerjee [12] stated that EPS cannot predict stock returns and hence can safely be considered statistically insignificant.

\section{Conceptual Framework and Hypotheses}

Based on the literature study and previous researches concluded that: a) the EVA, CR, NPM and EPS has positive correlation with the Stock Return and b) the DER has negative correlation with Stock Return, where the relation depicted in Figure-1 conceptual Framework and the hypotheses proposed as follows:

$\mathrm{H} 1$ = Economic Value Added (EVA) is thought to have a positive effect on stock returns.

$\mathrm{H} 2$ = Current Ratio (CR) is thought to have a positive effect on stock returns.

H3 = Debt to Equity Ratio (DER) is suspected to have a significant negative effect on stock returns.

H4 = Net Profit Margin (NPM) is suspected to have a significant positive effect on stock returns.

H5 = The Earning Per Share (EPS) is suspected to have a significant effect on stock returns.

\section{THE RESEARCH METHODOLOGY}

This study is a causal quantitative research with subject the Mining Sector Company listed on the Indonesia Stock Exchange in the 2012-2018 period, sample used is purposive sampling with criteria: 1) Companies engaged in the mining sector which are listed on the Indonesia Stock Exchange (IDX) during the observation period, namely the period 2012-2018, 2) Companies that conduct IPOs before 2012, and 3) 
The company periodically issues financial statements annually and has complete data during the observation period and makes a profit during the year, from 20122018. The research object is: Economic Value Added, Current Ratio, Debt to Equity Ratio, Net Profit Margin, and Earning Per Share as independent variables, and stock returns as dependent variable. The sample is 12 of 39 companies with 7 years, so total observations is 84 . Data collected from web site IDX and analyzing used SPSS 2.0 and E-views 10.0 version.

\section{THE RESULT}

\section{Research Object Description}

The object of research is the Mining Sector Company listed on the Indonesia Stock Exchange in the 2012-2018 period, The number of mining companies listed on the IDX is 39 of this amount 12 companies meets with sample criteria with total observations is = $12 \times 7=84$ respectively consisting of Stock Return, Economic Value Added, Current Ratio, Debt to Equity Ratio, Net Profit Margin and Earning Per Share.

\section{Description Analysis}

Descriptive statistics are used to analyze by describing or describing data that has been collected as it is without intending to make conclusions that apply to the public or generalizations [21]. In this research the descriptive statistical test will only see the mean, minimum maximum and standard deviation. Table-1 shows the result of statistic descriptive test and following the explanations:

\section{Stock Return (SR)}

SR has a mean value of 0.334025 . The highest value is 1.471900 at PT. Ratu Prabu Energi Tbk in 2016 and the lowest SR of 0.021900 found at PT. Elnusa Tbk in 2018. The standard deviation value of 0.272838 .

\section{Economic Value Added (EVA)}

EVA has a mean value of Rp.257,000,000,000. The highest value is Rp.230,542,496,438 at PT. Elnusa Tbk in 2015 and the lowest value of Rp. $68,328,730,242$. found in PT. Elnusa Tbk in 2013. The standard deviation value of Rp.558,000,000,000 .

\section{Current Ratio (CR)}

CR has a mean value of 2.258330. The highest value is 8.980600 at PT. Ratu Prabu Energi Tbk in 2017 and the lowest value of 0.140100 is in PT. Indo Tambangraya Megah Tbk in 2012. The standard deviation value of 1.435191 .

\section{Debt to Equity Ratio (DER)}

DER has a mean value of 0.971992 . The highest value is 3,922600 at PT. Radiant Utama Interinsco Tbk in 2012 and the lowest value of 0.108400 is in PT. Harum Energy Tbk 2015. The standard deviation value of 0.870428 .

\section{Net Profit Margin (NPM)}

NPM has a mean value of 0.168868 . The highest value is 3.133900 at PT. Citata Tbk in 2016 and the lowest value of PT. Indo Tambangraya Megah Tbk in 2015 . The standard deviation value of 0.387313 .

\section{Earning Per Share (EPS)}

EPS has a mean (average) of 12,62591. The highest value is 101.1873 at PT. Radiant Utama Interinsco Tbk in 2014 and the lowest value of 0.001100 at PT. Resource Alam Indonesia Tbk in 2018. The standard deviation value of 25.21452.

\section{Estimation of Panel Data Regression Model}

There are 3 approaches of the regression model which is the Common Effect, Fixed Effect and Random Effect approaches. The Common Effect Approach with The Common Effect panel data regression shown on Table-2, meanwhile the Fixed Effect Approach with The Fixed Effect panel data regression model shown on Table 3 and the Random Effect Approach with The Random Effect panel data regression model shown on Table-4.

\section{Selection of Panel Data Regression Model}

The selection will pas through 3 test which is Fixed Effect Test (Chow Test), Random Effect Test (Hausman Test and Lagrange Multiplier Test with the steps as follows:

\section{Fixed Effect Test (Chow Test)}

Chow Test will compare the Common Effect and the Fixed Effect model with hypothesis as:

\section{H0: Model Common Effect \\ H1: Model Fixed Effect}

$\mathrm{H} 0$ is rejected if the P-value is smaller than $\alpha$, $\mathrm{H} 0$ is accepted if the P-value is greater than the value of $\alpha$, with $\alpha$ value used is $5 \%$. The test resulted in Table 5 shown that Cross Section F is 0.3597 greater than 0.05 concluded selected model is Common Effect Model.

\section{Random Effect Test (Hausman Test)}

The Hausman Test will compare between Fixed Effect and random-effects model with the following hypothesis:

\section{H0: Random Effect Model \\ H1: Fixed Effect Model}

$\mathrm{P}$-value $<0.05$ then $\mathrm{H} 0$ is rejected, the fixed effect is chosen. If $p$ value $>0.05$ then the random effect model is selected. The result shown in Table- 6 where the value of Hausman probability is 0.3347 greater that 0.05 concluded that Random Effect Model is chosen. 
Lagrange Multiplier Test (LM-Test)

Lagrange Multiplier Test is executed to compare between the common effect and random effect with the hypothesis as follows:

\section{H0: Common Effect Model}

H1: Random Effect Model

HO is rejected if the value of Prob. BreuschPagan (BP-value) is smaller than the value of $\alpha$ Conversely, $\mathrm{H} 0$ is accepted if it is greater than the $\alpha$ value, the $\alpha$ value used is $5 \%$. The result of the test seen on Table-7 where the Breush-Pagan probability value is 0.0000 smaller than 0.05 concluded that Random Effect Model is chosen. The result summary of regression estimation model selection presented on Table-8.

\section{Panel Data Regression Model Formulation}

The result of Chow Test generates Common Effect Model, meanwhile Hausman and Lagrange Multiplier concludes Random Effect as model selected as depicted in Table-8, facing this condition Nachrowi and Hardius [22] stated that econometry expert had systematically proved if the panel data has amount of time (t) greater than the amount of individual (n) it is suggested to use the fixed effect model, conversely if the amount of time (t) smaller than amount of individual (n) it suggested to use the random effect model. This study has the $\mathrm{t}=7$ and the $\mathrm{n}=12$, where $\mathrm{t}<\mathrm{n}$, therefore the conclusion of selection is random effect model is chosen as formulated in Table 4 which represented in Table-9 and a multiple linear regression equation from the Random Effect obtained as follows:

Stock Return $=0.253988+2.28 \mathrm{E}-12 \mathrm{EVA}-$ $0.005439 \mathrm{CR}+0.011122 \mathrm{DER}+0.272922 \mathrm{NPM}$ $-0.001835 \mathrm{EPS}$

\section{Research Object Description}

The object of research is the Mining Sector Company listed on the Indonesia Stock Exchange in the 2012-2018 period, The number of mining companies listed on the IDX is 39 of this amount 12 companies meets with sample criteria with total observations is = $12 \times 7=84$ respectively consisting of Stock Return, Economic Value Added, Current Ratio, Debt to Equity Ratio, Net Profit Margin and Earning Per Share.

\section{Stock Return(SR)}

SR has a mean value of 0.334025 . The highest value is 1.471900 at PT. Ratu Prabu Energi Tbk in 2016 and the lowest SR of 0.021900 found at PT. Elnusa Tbk in 2018. The standard deviation value of 0.272838 .

\section{Economic Value Added (EVA)}

EVA has a mean value of Rp.257,000,000,000. The highest value is Rp.230,542,496,438 at PT. Elnusa Tbk in 2015 and the lowest value of Rp. $68,328,730,242$. found in PT. Elnusa Tbk in 2013. The standard deviation value of Rp.558,000,000,000 .

\section{Current Ratio (CR)}

CR has a mean value of 2.258330. The highest value is 8.980600 at PT. Ratu Prabu Energi Tbk in 2017 and the lowest value of 0.140100 is in PT. Indo Tambangraya Megah Tbk in 2012. The standard deviation value of 1.435191 .

\section{Debt to Equity Ratio (DER)}

DER has a mean value of 0.971992 . The highest value is 3,922600 at PT. Radiant Utama Interinsco Tbk in 2012 and the lowest value of 0.108400 is in PT. Harum Energy Tbk 2015. The standard deviation value of 0.870428 .

\section{Net Profit Margin (NPM)}

NPM has a mean value of 0.168868 . The highest value is 3.133900 at PT. Citata Tbk in 2016 and the lowest value of PT. Indo Tambangraya Megah Tbk in 2015. The standard deviation value of 0.387313 .

\section{Earning Per Share (EPS)}

EPS has a mean (average) of 12,62591. The highest value is 101.1873 at PT. Radiant Utama Interinsco Tbk in 2014 and the lowest value of 0.001100 at PT. Resource Alam Indonesia Tbk in 2018. The standard deviation value of 25.21452.

\section{Classical Assumption Test}

Since the result of selection model for panel data regression equation produces Random Effect Model so that classical asumption test not required [23].

\section{HYPOTHESES TEST \\ Coefficient of Determination}

Based on Table-9, shown that adjusted Rsquare value is 0.184509 or 18.45 indicates that the Economic Value Added, Current Ratio, Debt to Equity Ratio, Net Profit Margin, and Earning Per Share variables can explain Stock Return of $18.45 \%$ and the rest of $81.55 \%$ affected by variables outside model. The $\mathrm{R}$ Squared value of $23.36 \%$ indicates that the influence is not strong, because the correlation value $<0.50$.

\section{F-Test (Simultaneous)}

Based on Table-9 the F value obtained was 4.755842 with a significance level of 0.000761 . These results indicate that the regression model is feasible because the significance level is less than 0.05 .

\section{The T-test (partial)}

The results of the statistical $t$ test of Economic Value Added variable has a significance level of 0.0061 $<0.05$ which indicates that EVA has a significant effect on stock returns and hypothesis (H1) is accepted, while the Current Ratio variable has a value of $0.8043>0.05$ which indicates that $\mathrm{CR}$ does not have a significant effect on stock returns and hypothesis (H2) is rejected. The other shown that Debt to Equity Ratio has a value of 0.7659> 0.05 which indicates that DER has no significant effect on stock returns and the hypothesis 
(H3) is rejected, meanwhile Net Profit Margin variable has a significance level of $0.0003<0.05$ which indicates that NPM has a significant effect on stock returns, the hypothesis (H4) is accepted and the last that Earning Per Share variable has a significance level of 0.3400
$<0.05$ which indicates that the Earning Per Share hypothesis does not have a significant effect on stock returns, hypothesis (H5) is rejected. The Individual Parameter Test Statistics result summary presented in Table-10.

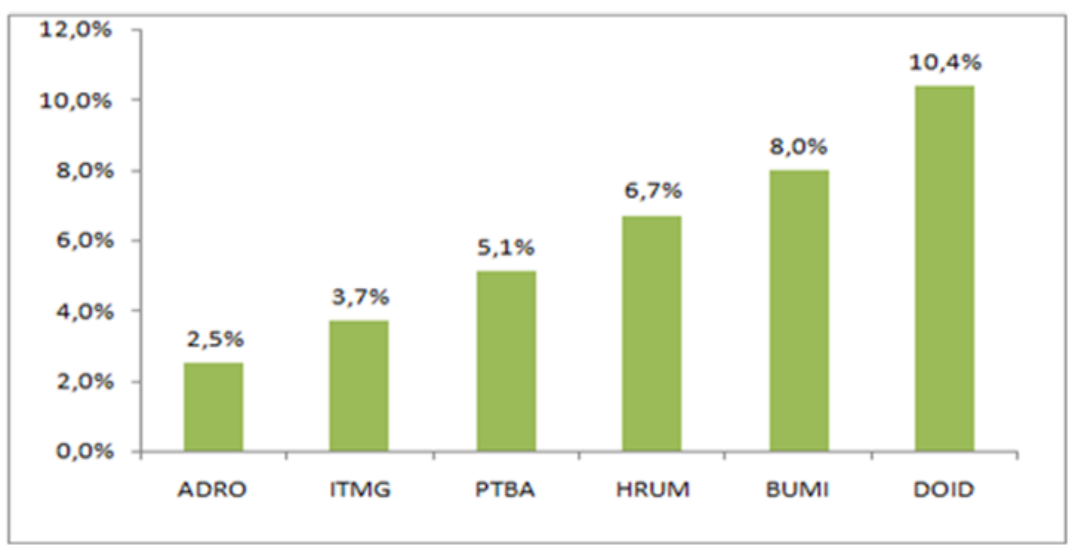

Graph-1: Intraday coal stock price movements 17 October 2016 Source: www.bareksa.com

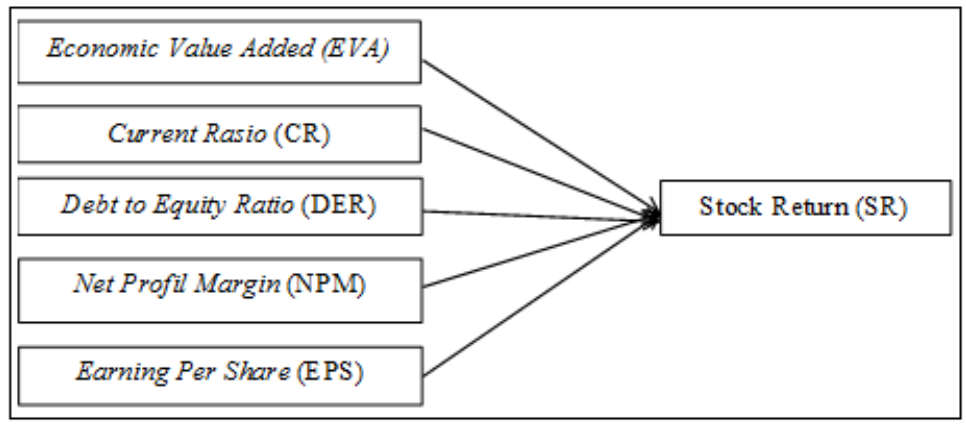

Fig-1: Conceptual Framework

\begin{tabular}{|c|c|c|c|c|c|c|}
\hline \multicolumn{7}{|c|}{ Sample: 20122018} \\
\hline & RETURN & EVA & $\mathrm{CR}$ & DER & NPM & EPS \\
\hline Mean & 0.334025 & $2.57 \mathrm{E}+10$ & 2.258330 & 0.971992 & 0.168868 & 12.62591 \\
\hline Median & 0.271350 & $1.58 \mathrm{E}+08$ & 1.808600 & 0.694450 & 0.074800 & 0.161400 \\
\hline Maximum & 1.471900 & $2.31 \mathrm{E}+11$ & 8.980600 & 3.922600 & 3.133900 & 101.1873 \\
\hline Minimum & 0.021900 & $-6.83 E+10$ & 0.140100 & 0.108400 & 0.000100 & 0.001100 \\
\hline Std. Dev. & 0.272838 & $5.58 \mathrm{E}+10$ & 1.435191 & 0.870428 & 0.387313 & 25.21452 \\
\hline Skewness & 2.003846 & 2.065849 & 2.063853 & 1.964749 & 5.848568 & 1.913055 \\
\hline Kurtosis & 8.339528 & 6.708484 & 8.493835 & 6.547944 & 42.76151 & 5.390798 \\
\hline Jarque-Bera & 156.0025 & 107.8832 & 165.2707 & 98.10103 & 6012.303 & 71.24263 \\
\hline Probability & 0.000000 & 0.000000 & 0.000000 & 0.000000 & 0.000000 & 0.000000 \\
\hline Sum & 28.05810 & $2.16 \mathrm{E}+12$ & 189.6997 & 81.64730 & 14.18490 & 1060.577 \\
\hline Sum Sq. Dev. & 6.178580 & $2.59 \mathrm{E}+23$ & 170.9611 & 62.88448 & 12.45093 & 52769.08 \\
\hline Observations & 84 & 84 & 84 & 84 & 84 & 84 \\
\hline
\end{tabular}

Source: E-views Result 
Table-2: Pooled Least Square Model (Common Effect) Dependent Variable: RETURN

Method: Panel Least Squares

Date: $02 / 20 / 20$ Time: $13: 47$

Sample: 20122018

Periods included: 7

Cross-sections included: 12

Total panel (balanced) observations: 84

\begin{tabular}{lllll}
\hline \hline Variable & Coefficient & Std. Error & t-Statistic & Prob. \\
\hline \hline C & 0.251707 & 0.077442 & 3.250257 & 0.0017 \\
EVA & $2.29 \mathrm{E}-12$ & $8.12 \mathrm{E}-13$ & 2.822513 & 0.0060 \\
CR & -0.004918 & 0.021791 & -0.225669 & 0.8220 \\
DER & 0.012549 & 0.037074 & 0.338500 & 0.7359 \\
NPM & 0.271961 & 0.071820 & 3.786688 & 0.0003 \\
EPS & -0.001868 & 0.001910 & -0.977890 & 0.3312 \\
\hline \hline R-squared & 0.234760 & Mean dependent var & 0.334025 \\
Adjusted R-squared & 0.185706 & S.D. dependent var & 0.272838 \\
S.E. of regression & 0.246204 & Akaike info criterion & 0.103440 \\
Sum squared resid & 4.728095 & Schwarz criterion & 0.277070 \\
Log likelihood & 1.655529 & Hannan-Quinn criter. & 0.173237 \\
F-statistic & 4.785767 & Durbin-Watson stat & 2.044240 \\
Prob(F-statistic) & 0.000723 & & \\
\hline \hline
\end{tabular}

Source: Eviews 10

Table-3: The Fixed Effect Model (Fixed Effect) Dependent Variable: RETUR

Method: Panel Least Squares

Sample: 2012201

Periods included: 7

Total panel (balanced) observations: 84

\begin{tabular}{lllll}
\hline \hline Variable & \multicolumn{2}{l}{ Coefficient Std. Error } & t-Statistic & Prob. \\
\hline C & 0.332795 & 0.110211 & 3.019609 & 0.0036 \\
EVA & $2.15 \mathrm{E}-12$ & $9.33 \mathrm{E}-13$ & 2.307573 & 0.0241 \\
CR & -0.020402 & 0.029556 & -0.690292 & 0.4924 \\
DER & -0.034073 & 0.052571 & -0.648129 & 0.5191 \\
NPM & 0.290218 & 0.081881 & 3.544384 & 0.0007 \\
EPS & -0.001889 & 0.003310 & -0.570714 & 0.5701 \\
\hline \hline
\end{tabular}

Cross-section fixed (dummy variables)

\begin{tabular}{llll}
\hline \hline R-squared & 0.353675 & Mean dependent var & 0.334025
\end{tabular}

Adjusted R-squared 0.194329 S.D. dependent var 0.272838

Sum squared resid 3993368 Schwarz criterion 0.688408

Log likelihood 8.748804 Hannan-Quinn criter. 0.394217

$\begin{array}{lll}\text { F-statistic } & 2.291443 & \text { Durbin-Watson stat } 2.356046\end{array}$

Prob(F-statistic) $\quad 0.009633$

Source: Eviews 10

Table-4: The Random Effect Model (Random Effect)

Dependent Variable: RETURN

Method: Panel EGLS (Cross-section random effects)

Date: 02/20/20 Time: $13: 58$

Sample: 20122018

Periods included: 7
Cross-sections included: 12

Cross- 84

Swamy and Arora estimator of component variances

\begin{tabular}{|c|c|c|c|c|}
\hline Variable & Coefficient & Std. Error & t-Statistic & Prob. \\
\hline $\mathrm{C}$ & 0.253988 & 0.077859 & 3.262166 & 0.0016 \\
\hline EVA & $2.28 \mathrm{E}-12$ & $8.10 \mathrm{E}-13$ & 2.817189 & 0.0061 \\
\hline $\mathrm{CR}$ & -0.005439 & 0.021876 & -0.248624 & 0.8043 \\
\hline DER & 0.011122 & 0.037224 & 0.298779 & 0.7659 \\
\hline NPM & 0.272922 & 0.071588 & 3.812394 & 0.0003 \\
\hline \multirow[t]{3}{*}{ EPS } & -0.001835 & 0.001912 & -0.959946 & 0.3400 \\
\hline & \multirow{2}{*}{\multicolumn{2}{|c|}{ Effects Specification }} & & \\
\hline & & & S.D. & Rho \\
\hline \multirow{3}{*}{$\begin{array}{l}\text { Cross-section random } \\
\text { Idiosyncratic random }\end{array}$} & & & 0.022045 & 0.0081 \\
\hline & & & 0.244136 & 0.9919 \\
\hline & \multicolumn{3}{|c|}{ Weighted Statistics } & \\
\hline R-squared & 0.233635 & \multirow{5}{*}{\multicolumn{2}{|c|}{$\begin{array}{l}\text { Mean dependent var } \\
\text { S.D. dependent var } \\
\text { Sum squared resid } \\
\text { Durbin-Watson stat }\end{array}$}} & 0.324882 \\
\hline Adjusted R-squared & 0.184509 & & & 0.271587 \\
\hline S.E. of regression & 0.245256 & & & 4.691732 \\
\hline F-statistic & 4.755842 & & & 2.056940 \\
\hline \multirow[t]{2}{*}{ Prob(F-statistic) } & 0.000761 & & & \\
\hline & \multicolumn{3}{|c|}{ Unweighted Statistics } & \\
\hline R-squared & 0.234740 & \multirow{2}{*}{\multicolumn{2}{|c|}{$\begin{array}{l}\text { Mean dependent var } \\
\text { Durbin-Watson stat }\end{array}$}} & 0.334025 \\
\hline Sum squared resid & 4.728219 & & & 2.041067 \\
\hline
\end{tabular}

Sourcs: Eviews 10 
Table-5: Fixed Effect Test (Chow Test) Result

Redundant Fixed Effects Tests

Equation: Untitled

Test cross-section fixed effects

\begin{tabular}{llll}
\hline \hline Effects Test & Statistic & d.f. & Prob. \\
\hline \hline & & & \\
Cross-section F & 1.120648 & $(11,67)$ & 0.3597 \\
Cross-section Chi-square & 14.186550 & 11 & 0.2228 \\
\hline \hline
\end{tabular}

Source: E-views 10 result

Table-6: Random Effect Test (Hausman Test) Result

\begin{tabular}{|c|c|c|c|}
\hline \multicolumn{3}{|c|}{ Correlated Random Effects - Hausman Test } & \\
\hline \multicolumn{3}{|c|}{ Equation: Untitled } & \\
\hline \multicolumn{3}{|c|}{ Test cross-section random effects } & \\
\hline Test Summary & Chi-Sq. Statistic & Chi-Sq. d.f. & Prob. \\
\hline Cross-section random & 5.717026 & 5 & 0.3347 \\
\hline
\end{tabular}

Table-7: Lagrange Multiplier (LM) Test Result

Lagrange multiplier (LM) test for panel data

Date: 02/20/20 Time: 14:02

Sample: 20122018

Total panel observations: 84

Probability in ()

\begin{tabular}{llll}
\hline \hline Null (no rand. effect) & $\begin{array}{l}\text { Cross-section } \\
\text { Alternative }\end{array}$ & $\begin{array}{l}\text { Period } \\
\text { One-sided }\end{array}$ & Bothe-sided \\
\hline \hline \multirow{2}{*}{ Breusch-Pagan } & 0.000274 & 23.95071 & 23.95098 \\
& $(0.9868)$ & $(0.0000)$ & $(0.0000)$ \\
Honda & -0.016557 & 4.893946 & 3.448835 \\
& $(0.5066)$ & $(0.0000)$ & $(0.0003)$ \\
King-Wu & -0.016557 & 4.893946 & 3.926852 \\
& $(0.5066)$ & $(0.0000)$ & $(0.0000)$ \\
GHM & -- & - & 23.95071 \\
& -- & - & $(0.0000)$ \\
\hline \hline
\end{tabular}

Source: Eviews 10

Table-8: The Summary Result of Model Selection

\begin{tabular}{|l|l|l|}
\hline No & Regression Estimation Model & Result \\
\hline 1 & Chow Test & Common Effect Model \\
\hline 2 & Hausman Test & Random Effect Model \\
\hline 3 & Lagrange Multiplier Test & Random Effect Model \\
\hline
\end{tabular}

Source: Data Processed 
Table-9: Random Effect Model

Dependent Variable: RETURN

Method: Panel EGLS (Cross-section random effects)

Date: $02 / 20 / 20$ Time: $13: 58$

Sample: 20122018

Periods included: 7

Cross-sections included: 12

Total panel (balanced) observations: 84

Swamy and Arora estimator of component variances

\begin{tabular}{|c|c|c|c|c|}
\hline Variable & Coefficient & Std. Error & t-Statistic & Prob. \\
\hline $\mathrm{C}$ & 0.253988 & 0.077859 & 3.262166 & 0.0016 \\
\hline EVA & $2.28 \mathrm{E}-12$ & $8.10 \mathrm{E}-13$ & 2.817189 & 0.0061 \\
\hline $\mathrm{CR}$ & -0.005439 & 0.021876 & -0.248624 & 0.8043 \\
\hline DER & 0.011122 & 0.037224 & 0.298779 & 0.7659 \\
\hline NPM & 0.272922 & 0.071588 & 3.812394 & 0.0003 \\
\hline \multirow[t]{3}{*}{ EPS } & -0.001835 & 0.001912 & -0.959946 & 0.3400 \\
\hline & \multirow{2}{*}{\multicolumn{2}{|c|}{ Effects Specification }} & & \\
\hline & & & S.D. & Rho \\
\hline \multirow{3}{*}{$\begin{array}{l}\text { Cross-section random } \\
\text { Idiosyncratic random }\end{array}$} & & & 0.022045 & 0.0081 \\
\hline & & & 0.244136 & 0.9919 \\
\hline & \multicolumn{4}{|c|}{ Weighted Statistics } \\
\hline R-squared & 0.233635 & Mean de & ent var & 0.324882 \\
\hline Adjusted R-squared & 0.184509 & S.D. dep & at var & 0.271587 \\
\hline S.E. of regression & 0.245256 & Sum squ & resid & 4.691732 \\
\hline F-statistic & 4.755842 & Durbin- & n stat & 2.056940 \\
\hline \multirow[t]{2}{*}{ Prob(F-statistic) } & 0.000761 & & & \\
\hline & \multicolumn{4}{|c|}{ Unweighted Statistics } \\
\hline R-squared & 0.234740 & Mean de & ent var & 0.334025 \\
\hline Sum squared resid & 4.728219 & Durbin- & n stat & 2.041067 \\
\hline
\end{tabular}

Sourcs: Eviews 10

Table-10: The Summary of Individual Parameter Statistic Test

\begin{tabular}{|c|c|c|}
\hline No & Explanation & Result \\
\hline H1 & Economic Value Added has positive effect on Sock Return & Economic Value Added has positive effect on Stock Return \\
\hline $\mathrm{H} 2$ & Current Ratio has positive effect on Stock Return & Current Ratio does not have significance effect on Stock Return \\
\hline H3 & Debt Equity Ratio has negative effect on Stock Return & $\begin{array}{r}\text { Debt to Equity Ratio does not have significance effect on Stock } \\
\text { Return }\end{array}$ \\
\hline $\mathrm{H} 4$ & Net Profit Margin has positive effect on Stock Return & $\begin{array}{r}\text { Net Profit margin has a significance positive effect on stock } \\
\text { return }\end{array}$ \\
\hline H5 & The Earning Per Share has positive Effect on Stock Return & $\begin{array}{r}\text { The Earning Per Share does not have significance positive } \\
\text { effect on Stock Return }\end{array}$ \\
\hline
\end{tabular}

Source: Data Processed, 2020

\section{DISCUSSION}

The effect of Economic Value Added on Stock Return

The result of $t$ test of Economic ValueAdded variable has a significance level of $0.0061<0.05$ which indicates that EVA has a significant effect on stock returns. it is supported the theory that a positive EVA reflects a good performance in the form of Stock Return, the company succeeded in creating value and it is line with studies by Babatunde, and Evuebie [9], Dedi et al., [10], Adil and Muhammad [11] and Banerjee [12].

\section{The effect of Current Ration on Stock Return}

The $t$ statistic test results value of $0.8043>0.05$ which indicates that $\mathrm{CR}$ does not have a significant effect on Stock Returns. The possible explanation is that on average the Current Ratio is not big enough for company to utilize all asset own in generating profit, that is why The Current Asset does not have significance positive affect on Stock Return.

\section{The effect of Debt Equity Ratio on Stock Return}

The $t$ statistic test of Debt to Equity Ratio has a value of $0.7659>0.05$ which indicates that DER has no negative significant effect on stock returns. This condition may be caused by the average DER of companies observed not big enough to become a risk for company's performance or conversely, not low enough to drive the firm performance to rise.

\section{The effect of Net Profit Margin on Stock Return}

The $\mathrm{t}$ statistic test shown that Net Profit Margin has a significance level of $0.0003<0.05$ which indicates that NPM has a positive significant effect on stock returns. A high NPM reflects the high firm could earn net profit, the high NPM will attract investor and it will drive the stock price to rise, NPM has a positive correlation with the Stock Return. This theory supported by studies of Maryam [18].

\section{The effect of Earning per Share on Stock Return}

The $\mathrm{t}$ statistical test shown that Earning Per Share variable has a significance level of $0.3400<0.05$ 
which indicates that the Earning Per Sharedoes not have a significant effect on Stock Returns, it is may be caused by the amount of Earning Per Share not enough to make positive correlation between Earning Per Share and Stock Return happened). The higher the EPS, the more success the management in attaining profit, the more attracted investor to make financial decision an at the end will drive the Stock Return. The Earning Per Share not high enough to drive Stock Return by the action of the investor.

\section{CONCLUSION AND SUGGESTIONS Conclusion}

The influence of Economic Value Added and Financial Performance represented by Current Ratio, Debt Equity Ratio Net Profit Margin and Earning Per Share on Stock Return is only in small portion and not strong. The Economic Value Added and only one of financial performance variable which Net Profit Margin has significance effect on Stock Return and the rest variables Debt to Equity Ratio, Current Asset and Earning Per Share does not effect. This research implies that management of the company advised to consider Economic Value Added and Financial Performance in their strategy in their whole performance.

\section{Suggestion}

It is suggested to firm management to consider to value concept and financial performance in the strategy to attain the company's goal and recommended to next researches to re-examined variables that presented financial performance as determinants of Stock Return to obtain the comprehensive information about the influence of these variables on Firm's Stock Return.

\section{REFERENCES}

1. Irham, F. (2015). Analisis Laporan Keuangan. Alfabeta. Bandung.

2. Meckling, W. H., \& Jensen, M. C. (1976). Theory of the firm: Managerial behavior, agency costs and ownership structure. Journal of financial economics, 3(4), 305-360.

3. Irham, F. (2014). Analisis Laporan Keuangan. Alfabeta, Bandung.

4. Jogiyanto, H. (2013). Teori Portofolio dan Analisis Investasi. BPFE Yogyakarta, Edisi Kedelapan, Yogyakarta.

5. Bodie, Z., Kane, A., Marcus, A. J. (2010). Investment, Mc Graw Hill.

6. Amin, W. T. (2008). Pengantar Konsep Nilai Tambah Ekonomi (EVA) dan Value Based Management (VBM). Jakarta Harvindo.

7. Suad, H., \& dan Enny, P. (2012). Dasar-dasar Manajemen Keuangan. Edisi 6. Yogyakarta UPP STIM YKPN.

8. Brigham, F. E., \& Houston, J. F. (2011). Dasardasar Manajemen Keuangan Buku 2. Jilid 11. Jakarta Salemba Empat.
9. Babatunde, A. A., \& Evuebie, O. C. (2017). The impact of economic value added (EVA TM) on stock returns in Nigeria. Scholar's Journal of Economics, Business and Management, 4(2), 8993.

10. Kusmayadi, D., Rahman, R., \& Abdullah, Y. (2018). Analysis of the Effect of Net Profit Margin, Price to Book Value, And Debt to Equity Ratio on Stok Return. International Journal of Recent Scientific Research, 9(1), 28091-28095.

11. Adil, P., \& Muhammad, R. (2019). Asymmetric impact of economic value-added dynamics on market value of stocks in Pakistan stock exchange, a new evidence from panel cointegration, FMOLS and DOLS. Cogent Business \& Management.

12. Banerjee, A. (2019). Predicting Stock Return of UAE Listed Companies Using Financial Ratios. Accounting and Finance Research. 8(2).

13. Mulyawan, S. (2015). Manajemen Keuangan. Pustaka Setia. Bandung.

14. Kasmir. (2016). Analisis Laporan Keuangan. Jakarta: Raja Grafindo Persada.

15. Obala, F., \& Olweny, T. (2018). Financial Performance and Stock Returns among Listed Banks in Kenya. International Journal of Economics, Commerce and Management. 6(5).

16. Halim, A., \& Dan, S. (2013). Manajemen Keuangan. BPFE UGM, Yogyakarta.

17. Brigham, F., dan Houston, E., \& Joel, F. (2013). Dasar-dasar Manajemen Keuangan. Jakarta Salemba Empat.

18. Maryyam, A. (2016). Impact of Firms' Performance on Stock Returns (Evidence from Listed Companies of FTSE-100 Index London, UK). Global Journal of Management and business research: D Accounting and Auditing. 16(1).

19. Darmadji, T., \& dan Fakhruddin. (2012). Pasar Modal Di Indonesia. Edisi. Ketiga. Jakarta: Salemba Empat.

20. Allozi, N. M., \& Obeidat, G. S. (2016). The Relationship between the Stock Return and Financial Indicators (Profitability, Leverage): An Empirical Study on Manufacturing Companies Listed in Amman Stock Exchange. Journal of Social Sciences (COES\&RJ-JSS), 5(3), 408-424.

21. Rasyid, R. H. A. (2014). Sugiyono.(2014).“Pengaruh Kepuasan Konsumen, Kepercayaan Dan Layanan Terhadap Loyalitas Berbelanja Pada Carrefour Surabaya”. Jurnal Ilmu \& Riset Manajemen, 3(12), 1-20.

22. Nachrowi, N. D., \& dan Hardius, U. (2006). Pendekatan populer dan Praktis Ekonometrika untuk Analisis Ekonomi dan Kenangan. Jakarta: LPFE Universitas Indonesia.

23. Indra-Sakti, S. M, (2018). Analisis Regresi Data Panel Menggunakan Eviews. Universitas Esa Unggul, Jakarta Barat. 